Estudios sobre armas antiguas, arte militar y vida cultural en oriente y occidente XXXII (2012), pp. 87-102

ISSN : 0436-029X

doi: 10.3989/gladius.2012.0005

\title{
THE METALLOGRAPHIC EXAMINATION OF SWORD NO. 438 AS PART OF A SYSTEMATIC SURVEY OF SWORDS FROM THE EARLY MEDIEVAL STRONGHOLD OF MIKULČICE, CZECH REPUBLIC
}

\author{
EXAMEN METALOGRÁFICO DE LA ESPADA NO. 438 EN EL MARCO DE UN \\ ESTUDIO SISTEMÁTICO DE LAS ESPADAS DE LA FORTALEZA BAJOME-DIEVAL \\ DE MIKULČICE, REPÚBLICA CHECA
}

POR

JIŘí HoŠEK*, JIŘí KošTA ${ }^{* *}$, PATRICK BÁRTA***

\begin{abstract}
Resumen
The paper deals with a metallographic examination of a sword from grave No. 438, which was uncovered at the site of Mikulčice (Hodonín county), a former early medieval stronghold in Moravia (Czech Republic). Mikulčice was one of the main power centres of the Great Moravia - the first state formed by Slavs north of the Danube River - which was created in the first third of the 9th century and ended at the beginning of the 10th century. The sword, provided with a single flattened hemispherical pommel (Petersen X type), has a blade bearing an inscription that is no longer legible. According to the results of metallographic examination, the blade was hardened and consists of steel cutting edges welded on a core, which was composed of steel side-plates and a middle strip of iron or low-carbon steel. It was an excellent sword, undoubtedly one of the best swords excavated in Mikulčice.
\end{abstract}

El artículo trata de un examen metalográfico de una espada de la tumba número 438, que fue descubierta en el yacimiento de Mikulčice (Hodonín Condado), antiguo bastión bajomedieval en Moravia (República Checa). Mikulčice fue uno de los centros de poder principales del Gran Moravia - la primera agrupación estatal de los eslavos del norte del río Danubio - que se creó en el primer tercio del siglo IX y fue abolido al comienzo del siglo X. La espada, que cuenta con un pomo aplanado hemiesféri-co (Petersen tipo X), tiene una hoja con una inscripción que ya no es legible. De acuerdo con los resulta-dos del examen metalográfico, la hoja fue endurecida y se compone de filos de corte de acero, soldados a un núcleo. Éste está compuesto de placas laterales de acero y una franja central de hierro o de acero dulce. Era una espada excelente, sin duda, una de las mejores espadas jamás excavadas en Mikulčice.

\section{Keywords - Palabras Clave}

Archaeometallurgy; Metallography; Early Medieval sword; Blade inscription; Great Moravia; Mikulčice. Arqueometalurgia; Metalografia; Espada bajomedieval; Inscripción en la hoja; Gran Moravia; Mikulčice.

* Archaeometallurgist; Institute of Archaeology of the AS CR, Prague, v.v.i.; Letenská 4, 11801 Prague, Czech Republic. E-mail: hosek@arup.cas.cz

** Archaeologist; National Museum; Václavské náměstí 68, 11579 Prague, Czech Republic. E-mail: jiri.kosta@ seznam.cz

${ }^{* * *}$ Swordsmith; Templ - replicas of historical arms; Jámy 5, 64200 Bosonohy, Czech Republic. E-mail: templ@ templ.net 


\section{INTRODUCTION}

The Early Medieval stronghold of Mikulčice, (Hodonín county; Czech Republic), was one of the main centres of power in Great Moravia. This, the first Slavic state to the north of the Danube River, was established during the first third of the $9^{\text {th }}$ century, and came to an end at the beginning of the $10^{\text {th }}$ century as a consequence of internal economic and political crisis and the invasion of the Hungarians into the Carpathian basin. Our knowledge of Mikulčice depends solely on the evidence of archaeological sources, although the importance of the site is enhanced by the good preservation of the whole residential area, which was situated on several sand dunes and islands within the floodplain of the Morava River (Poláček, 2002; Poláček - Mazuch - Baxa, 2006). Thanks to extensive archaeological excavations since 1954 (Poláček - Marek, 1995; 2005), the foundations of at least 10 churches, approximately 2500 Great Moravian inhumations scattered over a number of cemeteries, the remains of wooden bridges and a significant pre-Great Moravian central settlement, have been uncovered. The Great Moravian stronghold, which formerly covered an area of circa 10 hectares, was fortified by wood-and-clay walls whose front surfaces were covered with stones assembled without mortar, and consisted of outer and inner baileys (fig. 1). During the Great Moravian period, an extensive settlement formed around this stronghold.

A total of 16 swords have been discovered in graves at the site, and a further three parts of swords were identified in the settlement material (Košta, 2005). The significance of this set of swords from Mikulčice lies not only in the number of items, but also in the very informative archaeological context in which the swords were found. Within the Frankish territory, the burial rite of deposition of weapons into graves began to decline during the course of the $8^{\text {th }}$ century and we generally know about swords from the $9^{\text {th }}$ century only from riverbed finds or other finds without any detailed context. Finds from Moravia and Slovakia, together with those of other territories bordering the Frankish Empire - such as Croatia and SchleswigHolstein - thus form the basic evidence for describing the development of swords within the territory of the Frankish state itself. As a whole, the Mikulčice finds can be quite accurately dated to the Great Moravian period, which can be correlated with the course of the $9^{\text {th }}$ century and the beginning of the $10^{\text {th }}$ century. The latest Mikulčice swords were most likely buried not significantly later than the first decade of the 10th century. The tragic events of that period in Moravia had fatal consequences for the Mikulčice settlement. In many cases, the stratigraphy of those graves with swords or other grave goods allow even more precise dating.

As part of the systematic investigation of the Mikulčice swords, seven weapons have undergone archaeological and metallographic examination to date (Košta - Hošek, 2009; 2008; Hošek - Košta, 2008; 2007); similar work is planned on another four of these swords in the near future. This is the largest assemblage to be studied in this manner in the Czech Republic.

\section{THE SWORD FROM GRAVE NO. 438}

Find context: Grave No. 438 was richly furnished. The deceased was buried (at an age of 40-50 years) in a coffin with iron fittings. In addition to the sword, the grave goods included a battle-axe, a pair of spurs, a piece of gold leaf inserted as an obol in the mouth of the deceased, a pair of shears, a knife, an iron belt chape, a firesteel and a little wooden bucket. The grave was located in an extensive burial ground within the inner bailey (acropolis) around the largest church in Mikulčice - the so-called 3rd church built in the form of a three-aisle basilica (Košta 
- Hošek, 2009) (fig. 1). On the basis of both the grave goods and the stratigraphy, the grave itself can be dated to the period around the middle or the third-quarter of the 9th century.

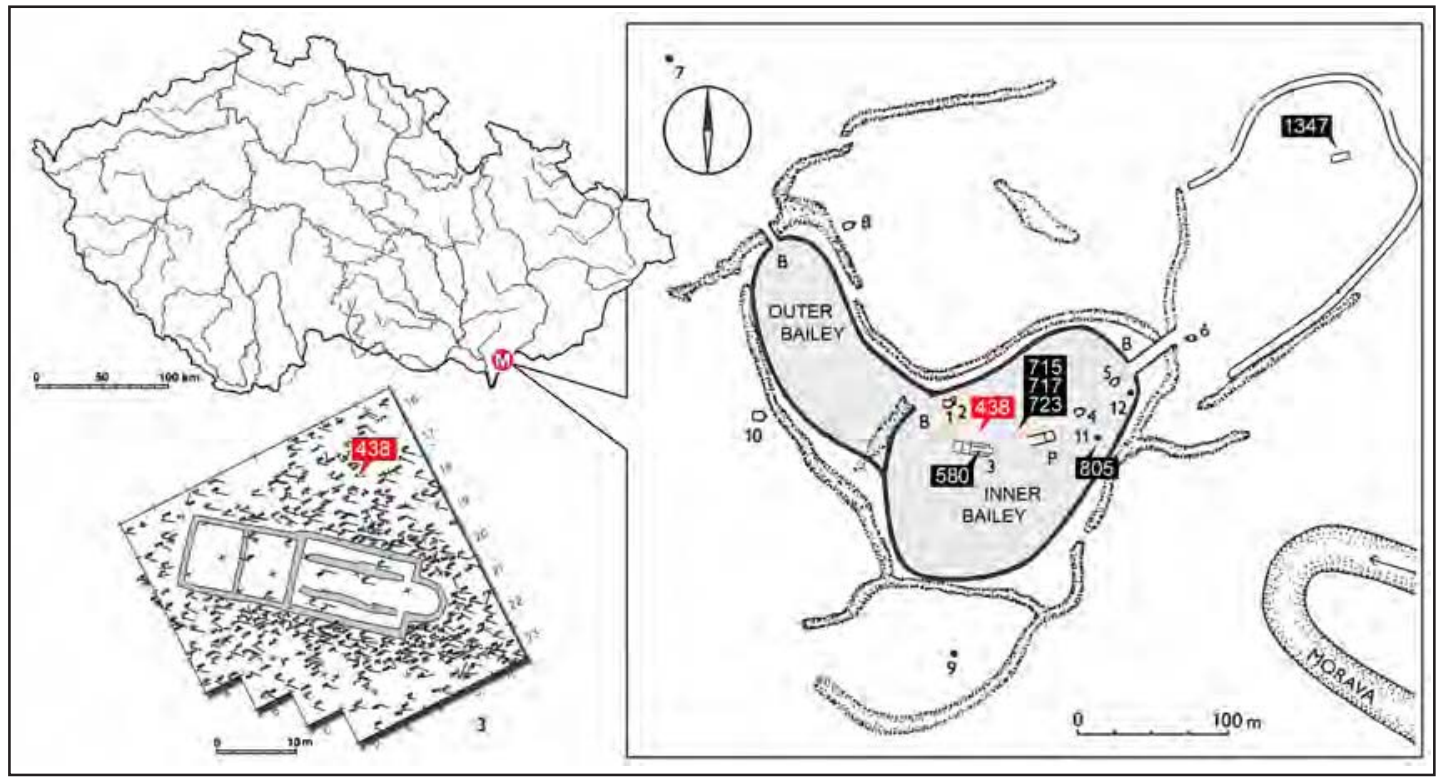

Figure 1. Stronghold of Mikulčice; plan of the site (the fortified area in grey): 1-12 - churches, $\mathrm{P}-$ «princely palace», B - gates. After J. Poulík (Poulík, 1975: obr. 14); position of the graves with swords examined up to date; 3 : third church and associated graveyard with position of the grave No.438. After L. Poláček and O. Marek, modified (2005: 64, Abb.41).

Sword description: The sword (fig. 2), is $950 \mathrm{~mm}$ long and weighs a mere $775 \mathrm{~g}$; the point of balance is located $170 \mathrm{~mm}$ from the crossguard. The sword has a slender, one-piece, semi-circular pommel (length $69 \mathrm{~mm}$, height $30 \mathrm{~mm}$, width $9 \mathrm{~mm}$ ), thanks to which one may classify the sword as a Petersen X type (Petersen, 1919: 158-167) or a Geibig 12-I type (Geibig, 1991: 56-60). The sword hilt (length $102 \mathrm{~mm}$ ) widens significantly toward the crossguard (from $18 \mathrm{~mm}$ to $31 \mathrm{~mm}$ ). The long crossguard (length $121 \mathrm{~mm}$, width $14 \mathrm{~mm}$, height $13 \mathrm{~mm}$ ) has the shape of a low and narrow block. The double-edged blade of the sword (length 805 $\mathrm{mm}$ ) is slender; beneath the crossguard it has a width of $55 \mathrm{~mm}$ that narrows gradually and almost in a regular fashion. The wide fuller runs for $758 \mathrm{~mm}$ from the crossguard; it is then replaced by a central ridge that runs to the tip. The blade of the sword is a Geibig type 3 (Geibig, 1991: 83-90). An inscription of an open circle or the letter $U$ was formed on one side of the blade $100 \mathrm{~mm}$ from the crossguard. The opposite side of the blade bears a damaged inscription along the entire width of the fuller between $40 \mathrm{~mm}$ and $170 \mathrm{~mm}$ from the crossguard; this inscription was produced using an inlay of twisted (pattern-welded) iron rods. Approximately seven characters or parts thereof have been preserved; today they are illegible even on X-ray images. The majority of these characters can be identified as the remnants of letters, but the end part of the inscription fades away completely. The size and the technology employed in the production of the inscription, as well as the appearance and dating of the weapon offer the possibility of identifying the piece as an «Ulfberht» type sword or a copy thereof; however, we cannot rule out other designs. The sword was inserted in a wooden, cloth-lined sheath. Petersen X/Geibig 12-I swords were common throughout Europe from the middle of the $9^{\text {th }}$ century through to the $11^{\text {th }}$ century. The studied sword is one of the oldest swords of this type. 


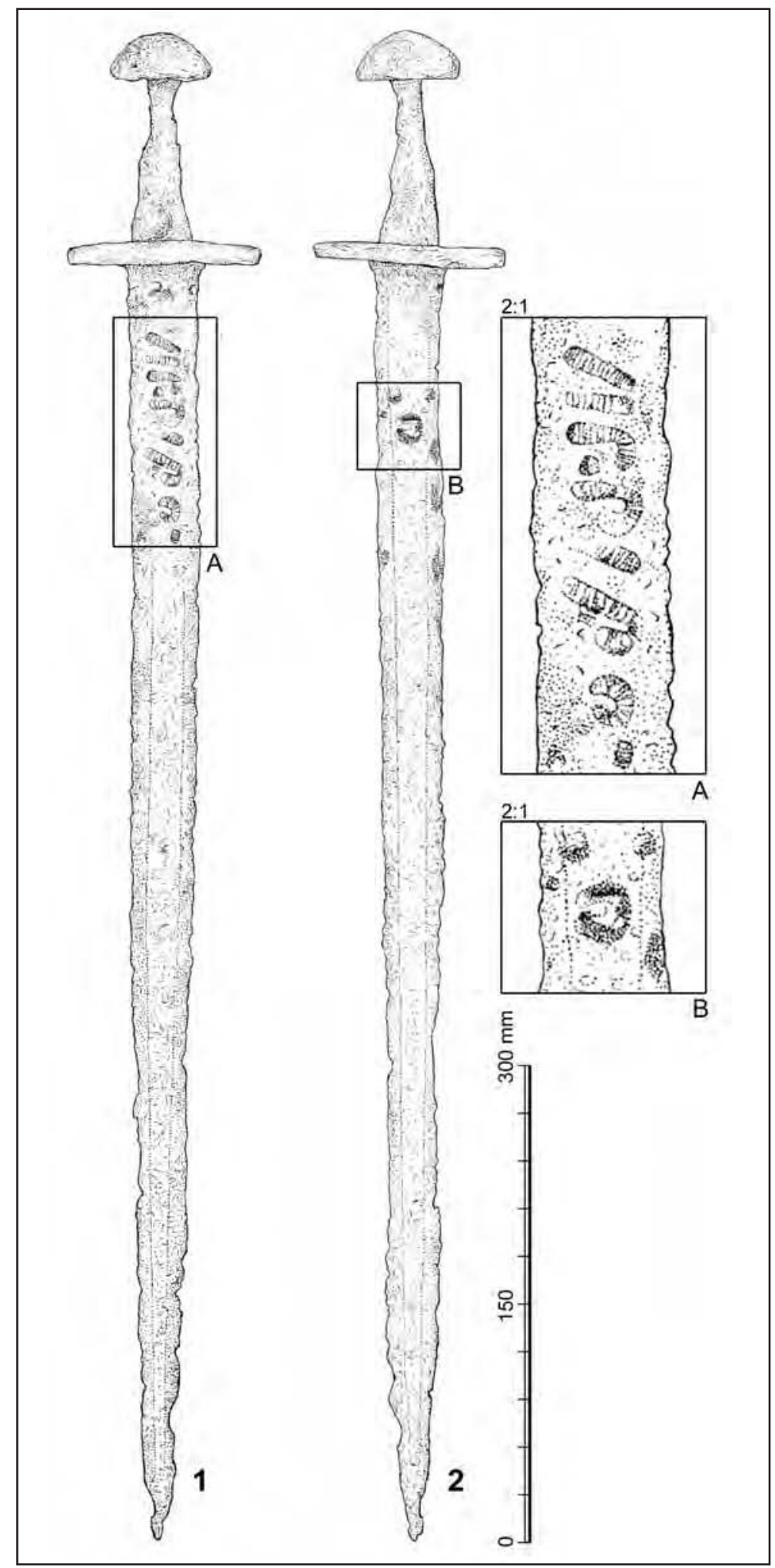

Figure 2. Sword from grave No. 438, Mikulčice; drawing by K. Urbanová. 
Metallographic examination: Four samples were taken from the sword: one from the side of the pommel (No. 1), one from the end of the crossguard (No. 2) and one from each side of the blade at different distances from the crossguard (No. 3 and No. 4). The samples were taken in order to obtain the most comprehensive possible information about the construction of the entire weapon. The metallographic samples provided to the laboratory at the Institute of Archaeology in Prague were observed first in an unetched condition, when (in accordance with the tradition of laboratory), the slag content of the metal was evaluated using the Jernkontoret scale. Then they were etched with 3\% nital and Oberhoffer's reagent. The microhardness was determined on the Vickers scale by a Wilson Wolpert 401MVD hardness tester.

Blade: The two samples from the blade are very similar, and they are documented together (figs. 3, 4). The matrix contains numerous slag inclusions, both coarse and fine, and corresponds to the stratified composition of many bloomery iron products. The border which marks the attachment of the cutting edge, the metal of which also contains slag, is well defined by a chain of fine inclusions. The slag content corresponds to a level of 3 to 4 on the Jernkontoret scale. After nital etching one may observe that the blade edge (Area I) is made up of bainite with a hardness of $476 \pm 18 \mathrm{HV} 0.5$. Area II, representing the sides of the blade, is also mostly bainitic (421 \pm 45 HV0.5). Areas III, IV and V are in the central parts of the core. Area III in proximity to Area I is still bainitic, though it gradually changes to a pearlite-ferric structure with 0.5 to $0.6 \% \mathrm{C}$ (grain size $7-8$ ASTM) with a hardness of $205 \pm 23 \mathrm{HV} 0.5$. Area IV has about $0.4 \% \mathrm{C}$ and a grain size of 7 ASTM. Area V is apparently just ferrite with only traces of pearlite, of grain size 7 ASTM, and a hardness of $123 \pm 8$ HV0.5.

Pommel: Sample No. 1 (pommel) (fig. 5), has in approximately half of its section only a few small slag inclusions (level 2 on the Jernkontoret scale); the second half has a significant amount of coarse inclusions (level 4-5 on the Jernkontoret scale). In an etched condition only the edges of the sample (Area I) are found to be slightly carburized. The carbon content does not exceed $0.2 \%$, and grain size is 7-8 ASTM; the hardness, however, is high ( $213 \pm 17 \mathrm{HV} 0.3)$. The majority of the surface is ferritic, with coarse grains (4 to 6 ASTM) and hardness $130 \pm 3$ HV0.3. In places the structure is also without distinct grain boundaries; relief surface etching appears only slightly and the hardness is $165 \pm 14$ HV0.3. A number of randomly distributed areas containing greater or lesser amounts of phosphorus may be seen following etching with Oberhoffer's solution.

Crossguard: The material of sample No. 2 (crossguard) (fig. 5), contains randomly distributed slag particles of various sizes; some areas are relatively clean (level 2 on the Jernkontoret chart), others have a great number of inclusions (level 4-5 on the Jernkontoret scale). In an etched condition, Area I can be seen to contain coarser grains, with approximately $0.6 \% \mathrm{C}$ and a hardness of $234 \pm 10 \mathrm{HV} 0.3$. In its centre; towards the border with Area III, the microstructure becomes finer, the carbon content drops to around $0.3 \%$ and finally it gradually merges into the ferrite of Area III. Area II has around $0.35 \%$ carbon and a grain size of 8 ASTM; toward the border the carbon content drops to around $0.2 \%$ and a hardness of $125 \pm 5 \mathrm{HV} 0.3$. Area II is separated from the ferritic Area III (with coarse grains of 2-4 ASTM and a hardness of $125 \pm 5$ HV0.3) by a welding line with elongated slag inclusions. The distribution of phosphorus-rich areas in the sample appears to be random. 


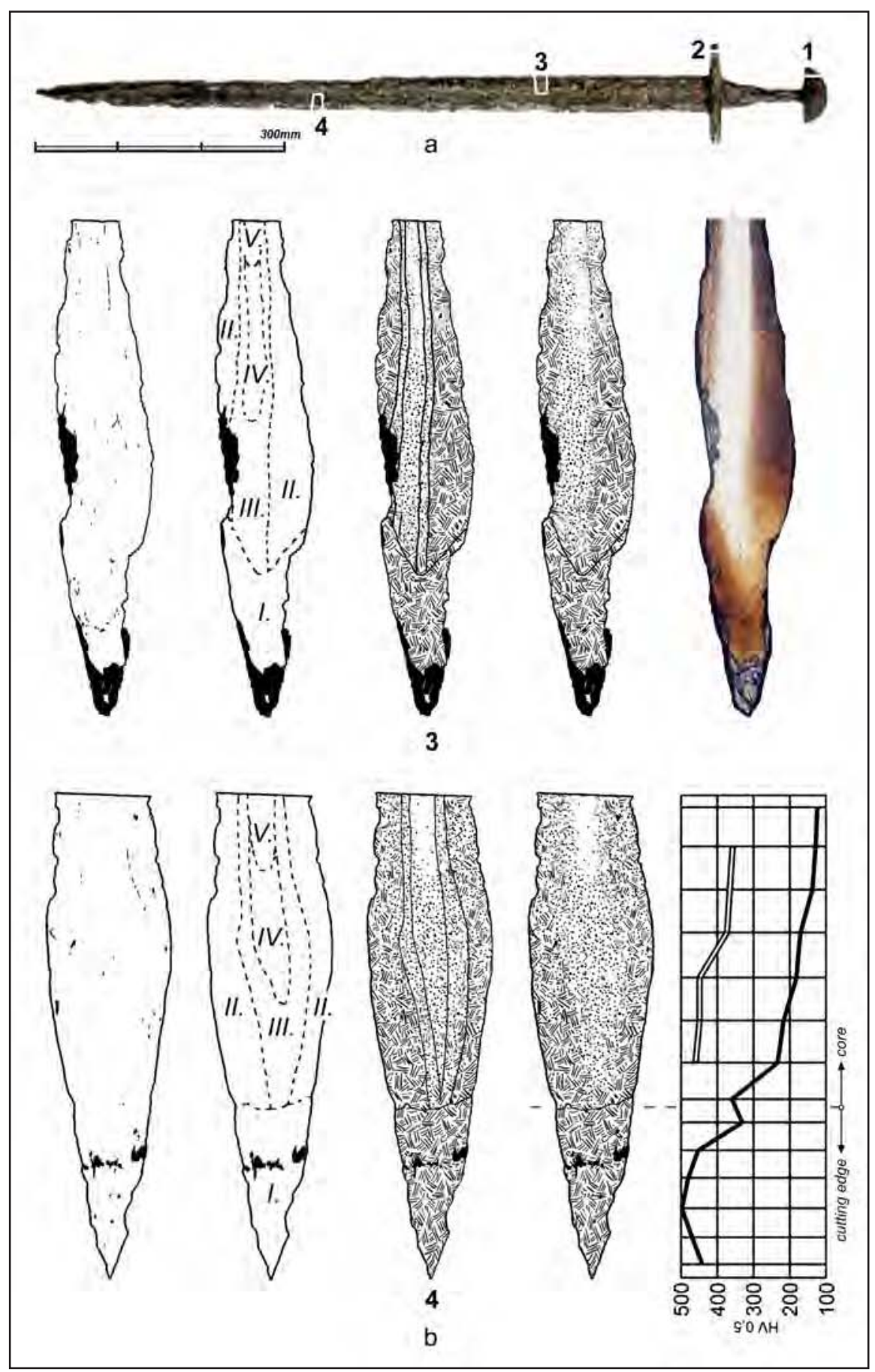

Figure 3. Sword No. 438, Mikulčice; a - the sword studied and the sampling method utilized; $b$-schematic drawings of blade samples 3 and 4; in each case - reading from the left: unetched state, layout of described area; after nital etching, with an indication of the main welds; after nital etching, with an indication of the joining of the edges and with inclusions; [extreme right middle] macro photo of sample 3 (slightly etched with nital); [extreme right below] variation of hardness in sample 4. Drawings and photos by J. Hošek. 


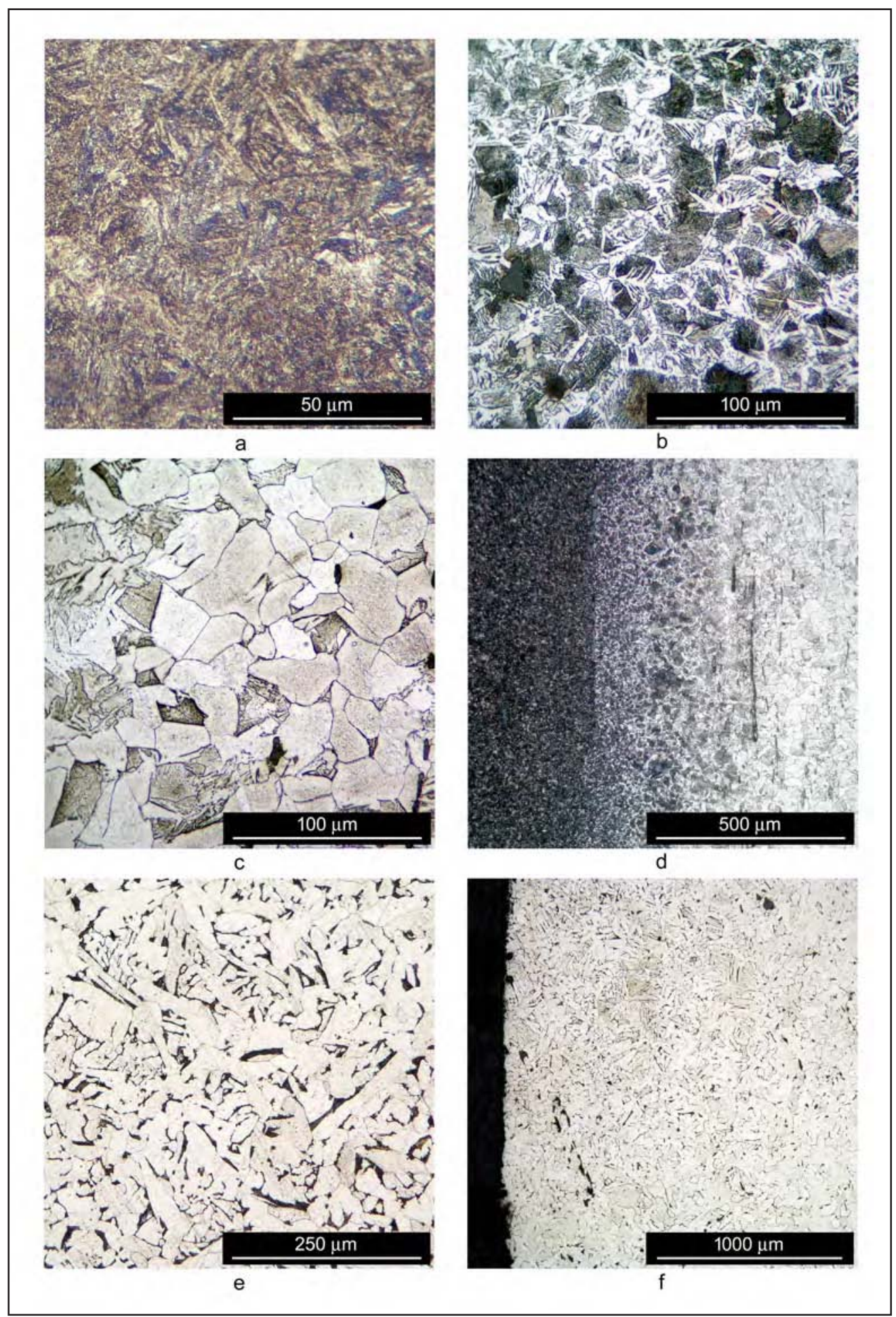

Figure 4. Sword No. 438, Mikulčice; a - bainite-type structure in cutting edges (area I), samples 3 and $4 ; \mathrm{b}$ - pearlite-ferrite structure in area III, samples 3 and 4; c - ferrite-pearlite area V, samples 3 and 4; $\mathrm{d}$ - transitions of areas II, III and V, samples 3 and 4; e - ferrite-pearlite zone (area I) in sample 1; f-overall view of area I, sample 1; all etched with Nital. 


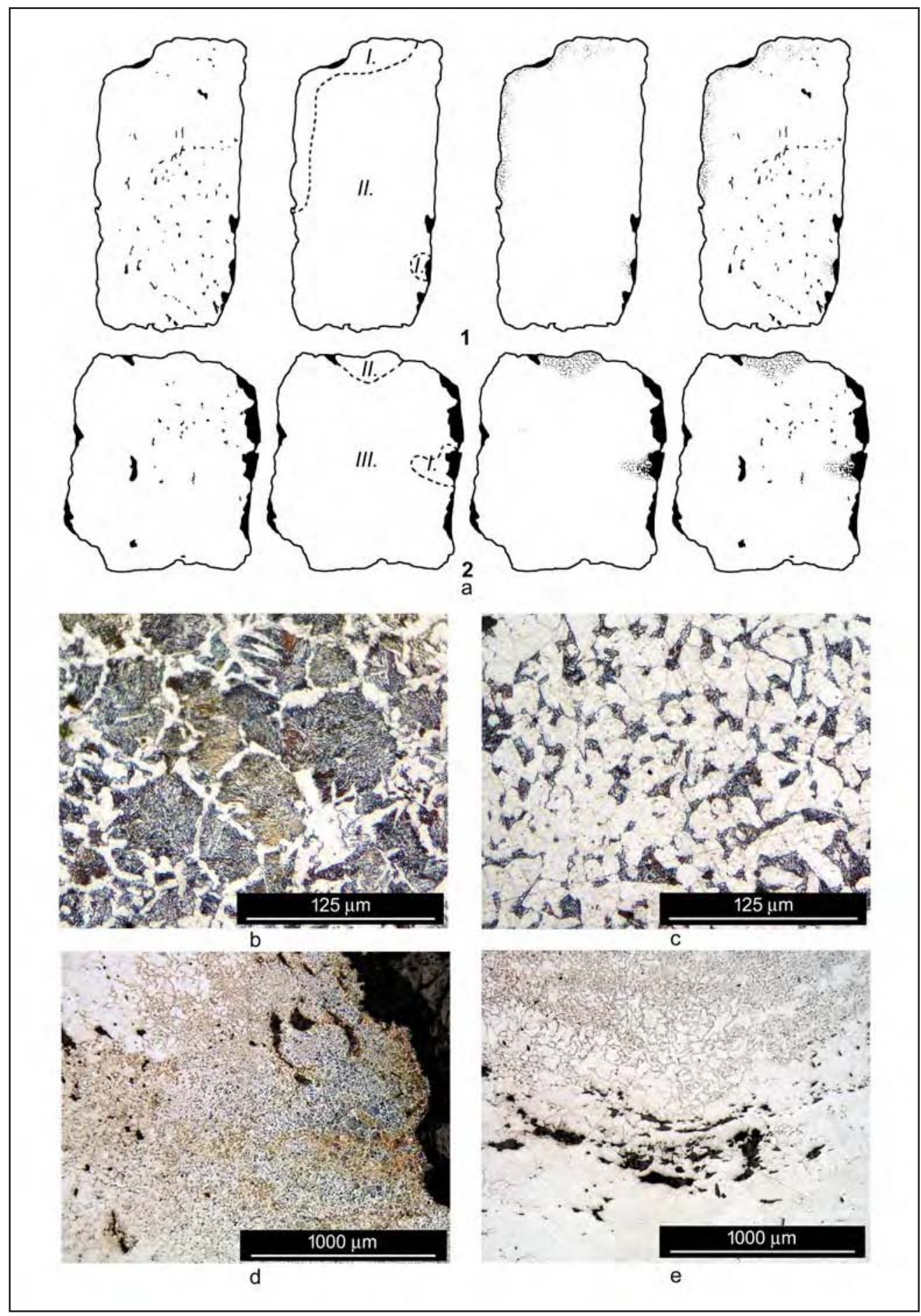

Figure 5. Sword No. 438, Mikulčice; a - schematic drawing of samples from pommel (1) and crossguard (2); Reading from the left: unetched state, layout of described areas; following Nital etching - without inclusions with inclusions; b - pearlite-ferrite zone (area I) in sample 2; c ferrite-pearlite zone (area II) in sample 2; $\mathrm{d}$ - overall view of area I, sample 2; e - overall view of area II, sample 2; all etched with Nital. 


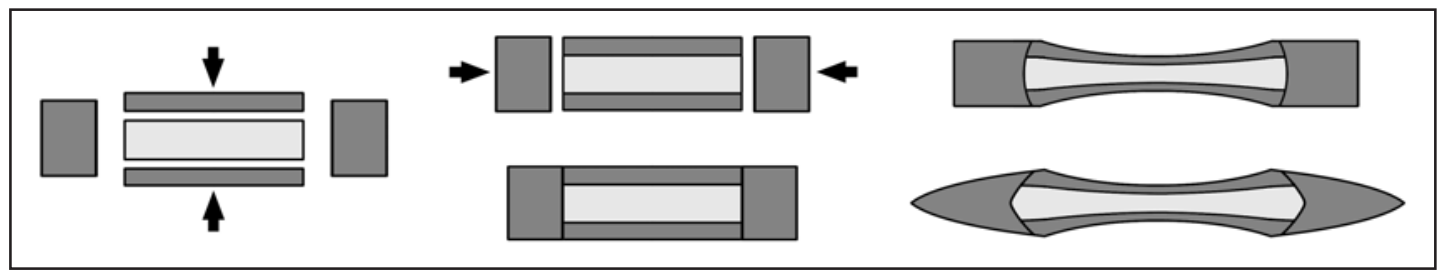

Figure 6. Presumed production method of the blade of sword No.438. Drawing by J. Hošek.

\section{ASSESSMENT}

The materials of the pommel and crossguard are virtually identical. Both parts were made from a highly heterogeneous iron. Neither the pommel nor the crossguard show traces of assembly, so they probably involved directly processed iron bloom. The carburization of several surface areas is so slight that it cannot be considered as intentional. The central part of the blade has an iron or low-carbon steel core to which the steel side strips were attached. Steel pieces were then welded to the joints of this semi-finished body, and the entire billet was shaped into the blade (fig. 6). This forging process led to the uneven deformation of the welded surfaces between the core and the cutting edges. The steel from the side pieces in the core and the cutting edges is apparently the same material, with approximately the same carbon content. The higher carburization of the central part of the core near the cutting edges may be explained by the diffusion of carbon from the adjacent steel parts (the edges and side strips). The entire blade was hardened by some form of heat-treatment, probably a slack-quench of some sort, since the edges formed neither an all-martensite microstructure nor one of unambiguous tempered martensite. Hence, the weapon shows considerable competence in its forge work and heat treatment of the blade.

The sword's physical characteristics are further proof of its quality. The ratio of the sword's weight to the length of the blade is a mere $0.96 \mathrm{~g} / \mathrm{mm}$. The distance of the weapon's point of balance from the crossguard is $17.9 \%$ of the length of the sword, which is a very fine characteristic in comparison with other swords from the same period, especially when we consider that due to the light, slender pommel, the sword must have been mainly balanced by making the blade lighter. The distance of the point of balance from the crossguard, the distinct narrowing of the blade (the ratio of the blade width at the crossguard and near the tip) and its taper indicate that in addition to the standard cutting or slashing function, the sword was also intended for thrusting. In order to simplify and improve the accuracy of handling the sword when thrusting, the weight should be shifted closer to the crossguard so that the weapon will react easily and sensitively to wrist motion; in contrast, for slashing it is better to move the point of balance away from the crossguard - the sword in this case would have greater kinetic energy when slashing. In the period of its manufacture, such an emphasis on the thrusting function is relatively uncommon and in fact anticipates future technical advances. These parameters and the overall construction of the sword from grave No. 438 clearly make it one of the finest examples of the Mikulčice swords.

Blades of analogous construction would generally have had steel edges and their central parts would consist either of steel side-parts attached to an iron or low-carbon steel core or they would be entirely steel with heterogeneous or multibanded structure. This type of blade has been found in numerous weapons: e.g. in the sword (580/3) from the Mikulčice basilica ( $9^{\text {th }}$ century; Košta - Hošek, 2008a), the find from the princely grave in Kolín ( $9^{\text {th }}$ century; Pleiner, 1962: 164. T. LXII; Košta - Hošek, 2008b: 17, fig. 12), the sword from Nemilany (9 $9^{\text {th }}$ to $10^{\text {th }}$ century; Selucká et al., 2002; Kalábek, 2002), the swords from the Old Russian burial grounds of Gnezdovo (No. 12; 10th century) and Priladozhye (No. 10 and 11: 10 ${ }^{\text {th }}$ century) and 
the town of Vshchizh (No. 6; $11^{\text {th }}-12^{\text {th }}$ century; Kolchin, 1953: 132-134, fig. 106), several of the swords taken from the River Thames (S7, S23 and S47; $9^{\text {th }}-10^{\text {th }}$ century; Tylecote - Gilmour, 1986: 156-158, Tab. N), and others.

Also worth noting in connection with the research results from sword No. 438 is the theory by A. Williams (2009a, b), who considers original »Ulfberht»-type swords to be those produced from hyper-eutectoid steels, (sometimes rather heterogeneous) which often contain more than $1 \%$ carbon and which could be a type of crucible steel. These blades are usually not quenched, since the hardness and strength of hyper-eutectoid steel were sufficient even without heat treatment for hardening. According to A. Williams, swords with the inscriptions +VLFBERH+T are usually made of such steels (+VLFBERH+T is the most common spelling of the inscription (Stalsberg, 2007)). Williams assumes that copies with a wide range of variations in their inscriptions represent more or less successful imitations using bloomery steel which then required hardening (such as the sword from Nemilany with the inscription spelled +VLFBERHT+ or the sword in Nürnberg with the inscription +VLFBEH+T, see Williams $(2009 \mathrm{~b}$ : 130, 132)). The illiterate purchasers could easily confuse these copies with their almost identical inscriptions and similarly hard edges with the original +VLFBERH+T swords (Williams, 2007: 239). In light of this theory, sword No. 438 could be such a copy with a variant inscription.

Additional Mikulčice swords examined include No. 580 (with an inlaid mark), No. 715 (with a pattern-welded blade), No. 717, No. 723 (perhaps with an inscription or mark), No. 805 and No. 1347. The basic characteristics of these swords are presented in the tables 1 to 7 at the end of the publication.

The basic methods used to produce the sword blades found to date in Mikulčice are presented in figure 7. The starting parts in individual constructions were pieces of steel, iron or pattern-welded metals. At the same time, it may be possible to further distinguish the manner in which these pieces were prepared - for example, between pieces without traces of welding (perhaps produced from a single larger piece of steel or iron), or between pieces welded from multiple smaller pieces arranged in various ways.

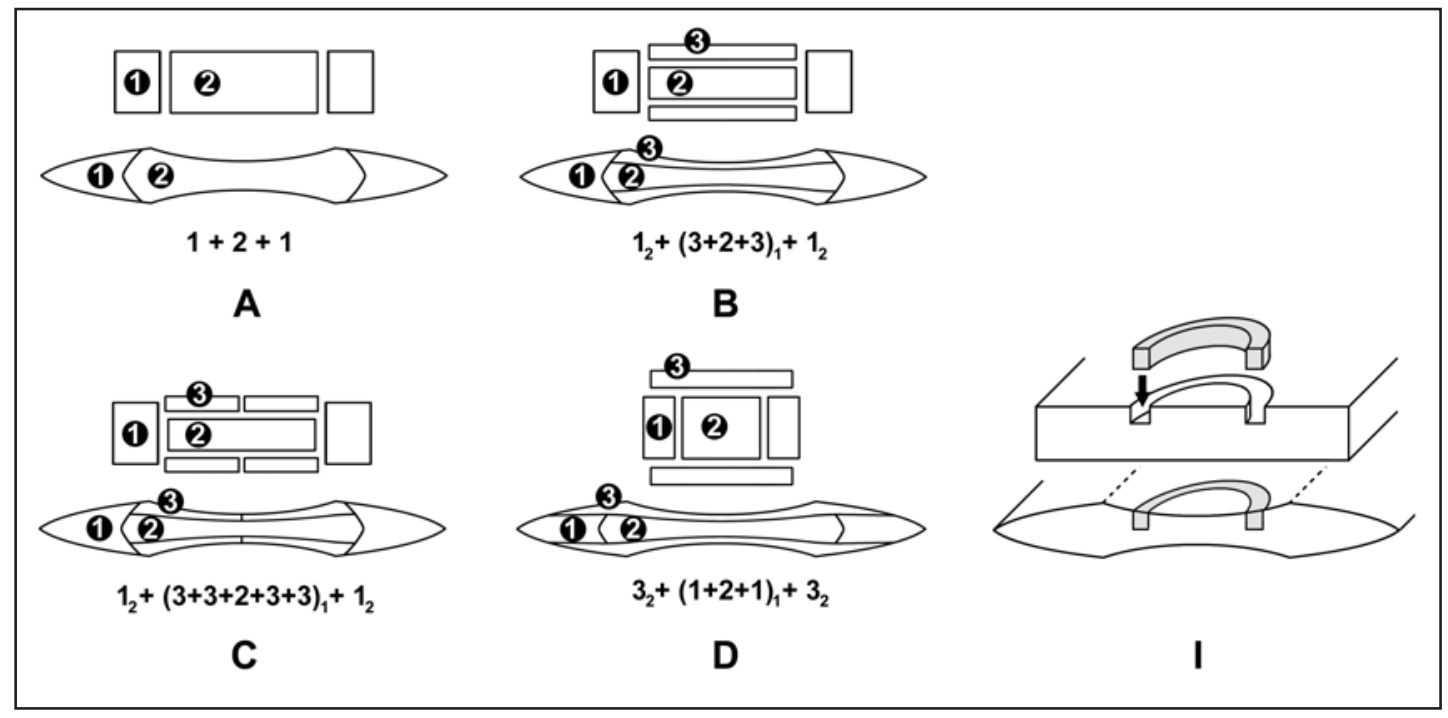

Figure 7. Methods of welding semi-finished pieces together to make the blades of Mikulčice swords (A -D). The method of blade inlaying (I). Drawing by J. Hošek. 
The most common procedures were the assembly of semi-finished pieces using methods A (fig.7: A) and B (fig.7: B). Method C (fig. 7: C) is a construction typical for pattern-welded blades; figure 7: D shows a less frequent and technologically more complicated method - a "sandwich" assembly. From the perspective of the time needed, production methods B, C and $\mathrm{D}$ are comparable, either with or without pattern-welding. In the second half of the 9 th century, the pattern-welded decoration of swords fell out of fashion and was replaced by the distinguishing of blades with inscriptions of letters or symbols forged into the surface of the blade (for the inlay method, see fig. 7: I), such as was used on our blade 438 .

\section{CONCLUSION}

Although the systematic study of the Mikulčice weapons is not yet complete, we can already distinguish several common characteristics in their production methods which may help us to discuss individual finds in a more useful manner. The most heavily decorated of the Mikulčice swords to have been examined to date is probably the find from grave No. 715, an older type weapon in this assemblage that was a surprisingly poor blade. Despite its patternwelding the sword lacks steel cutting edges, and its almost all-iron construction would have made the sword a very poor weapon. Current research on 9th and 10th century weapons seems to suggest that both pattern-welded swords made mostly of iron and pattern-welded swords made of iron and steel commonly appear in this period (Košta - Hošek, 2012; Hošek - Košta, 2011; Hošek - Mařík - Šilhová, 2008).

Though all-steel blades, or blades with large and hard steel edges, did not have such an impressive appearance without surface decoration, they nevertheless achieved superior strength and hardness. Perhaps it was their strength and hardness that became, sometime in the 9th century, the principal criterion for judging the quality and value of a weapon.

We find swords with steel cutting-edges and central parts all of steel or layers of steel and iron in the most opulently furnished graves and among the later Mikulčice weapons, usually swords with one-piece, semicircular Petersen type X pommels, these types of blades predominate. The decorative pattern-welded core was replaced by inscriptions of letters or symbols generally inlaid with twisted (pattern-welded) rods, and therefore it is possible to speak now of weapons with blades which bore visible signs of ostentation. The sword from grave No. 438, the study of which was described above, clearly belongs among such impressive weapons and can be regarded as one of the higher quality specimens in the assemblage of Mikulčice swords.

\section{ACKNOWLEDGEMENTS}

We would like to thank Alan Williams and Miguel Tuda Bragado for their help and corrections of the paper, which has been published with support of the Czech Science Foundation (project P405/12/2289).

\section{BIBLIOGRAPHY}

Geibig, A. (1991): Beiträge zur morphologischen Entwicklung des Schwertes im Mittelalter. OffaBücher 71, Neumünster.

Hošek, J. - Košta, J. (2007): «Meč z hrobu 723 v Mikulčicích a jeho metalografický průzkum». In $Z$ dějin hutnictví, vol.37, Praha, pp. 5-19. 
Hošek, J. - Košta, J. (2008): «Meč s damaskovanou čepelí z hrobu 715 v Mikulčicích a jeho metalografický průzkum». In $Z$ dějin hutnictví, vol.38, Praha, pp. 5-16.

Hošek, J. - Košta, J. (2011): «Raně středověký meč Petersenova typu Y z pohřebiště na akropoli hradiště v Libici nad Cidlinou (Česká republika). Pohled archeologie a metalografie» In Cum arma per aeva. Uzbrojenie indywidualne na przestrzeni dziejów. Toruń : Adam Marszałek, pp.42-73.

Hošek, J. - Mařík, J. - Šilhová, A. (2008): «Kanín, hrob 54 - průzkum hrobové výbavy». Archeologické rozhledy LX, pp. 310-328.

Kalábek, M. (2002): «Hrob s mečem “ULFBERHT” z Nemilan». In Archaeologia technica 13, Brno p. 32 .

Kolchin, B.A. (1953): Chornaya metallurgiya i metalloobrabotka v Drevnei Rusi (domongolski period), Materialy i issledovaniya po arkheologii SSSR, vol. 32. Moscow.

Košta, J. (2005): «Kollektion frühmittelalterlicher Schwerter aus dem großmährischen Zentrum in Mikulčice». In P. Kouřil (ed.) Die frühmittelalterliche Elite bei den Völkern des östlichen Mitteleuropas, Brno, pp.157-191.

Košta, J. - Hošek, J. (2008a): «Meč z hrobu 580 ve III. kostele v Mikulčicích. Př́íspěvek k diskusi o jednom ze zástupců nejvyšší staromoravské elity». In Studia Mediaevalia Pragensia, vol. 8, Praha, pp. 177-207.

Košta, J. - Hošek, J. (2008b): «Zbraně z knížecího hrobu z 9. století v Kolíně z pohledu archeologie a metalografie». Acta Militaria Mediaevalia IV, Kraków-Sanok, pp. 7-37.

Košta, J. - Hošek, J. (2009): «Raně středověké meče s jednodílnou polokruhovitou hlavicí (typ Petersen X / Geibig 12, var. I.). Pohled archeologie a metalografie». In P. Dresler, Z. Měřínský (eds.) Archeologie doby hradištní v České a Slovenské republice. Brno, pp. 109-126.

Košta, J. - Hošek, J. (2012): «Meč z hrobu 120 ze Staré Kouřimi - doklad raně středověké zbraně vyrobené z kelímkové oceli?», Archeologické rozhledy LXIV, pp. 157-175.

Petersen, J. (1919): De norske vikingesverd. En typologisk-kronologisk studie over vikingetidens vaaben. Videnskapssekapets Skrifter, Historisk-Filosofisk Klasse II, 1. Kristiania.

Pleiner, R. (1962): Staré evropské kovárststí. Praha: ČSAV.

Poláček, L. (2002): «Mikulčice». In Reallexikon der Germanischen Alterumskunde. Band 20. Berlin New York, pp.12-17.

Poláček, L. - Marek, O. (1995): «Die Grabungen in Mikulčice 1954-1992. Geschichte, Grabungsmethoden und Dokumentation». In F. Daim - L. Poláček (Hrsg.) Studien zum Burgwall von Mikulčice. Band 1. Brno: Archeologický ústav AV ČR, Brno. pp.9-358.

Poláček, L. - Marek, O. (2005): «Grundlagen der Topographie des Burgwalls von Mikulčice». In L. Poláček (Hrsg.) Studien zum Burgwall von Mikulčice. Band 7. Brno: Archeologický ústav AV ČR, Brno. pp.9-358.

Poláček, L. - Mazuch, M. - Baxa, P. (2006): «Mikulčice - Kopčany. Stav a perspektivy výzkumu». In Archeologické rozhledy, vol. 58. Praha, pp. 623-642.

Poulík, J (1975): Mikulčice. Sídlo a pevnost knižat velkomoravských, Praha.

Selucká, A. - Richtrová, A. - Hložek, M. (2002): «Konzervace železného meče ULFBERHT», In Archaeologia technica, vol. 13, Brno, pp.28-31.

Stalsberg, A. (2007): «ULFBERHT - kven var det?». Spor. vol. 2, pp.12-14.

Tylecote, R.F. - Gilmour, B.J.J. (1986): The Metallography of Early Ferrous Edge Tools and Edged Weapons. British Archaeological Reports - British Series 155, Oxford.

Williams, A. (2007): «Crucible steel in medieval swords». In S. LaNiece, D. Hook and P. Craddock (eds.), Metals and Mines. London. 233-241.

Williams, A. (2009a): «Hypereutectoid steel in Viking-age swords». In Archaeometallurgy in Europe 2007, Milano, pp. 262-271.

Williams, A. (2009b): «A metallurgical study of some Viking swords». Gladius, XXIX. 121-184. 
Tables 1 to 7 . Brief overview of the basic constructional data from sword 438 and six other swords examined (No. 580, 715, 717, 723, 805 and 1347) from the stronghold of Mikulčice. Only specimens taken from these blades are described here. The methods of welding the semi-finished pieces together to form the blade are those shown in Fig. 7.

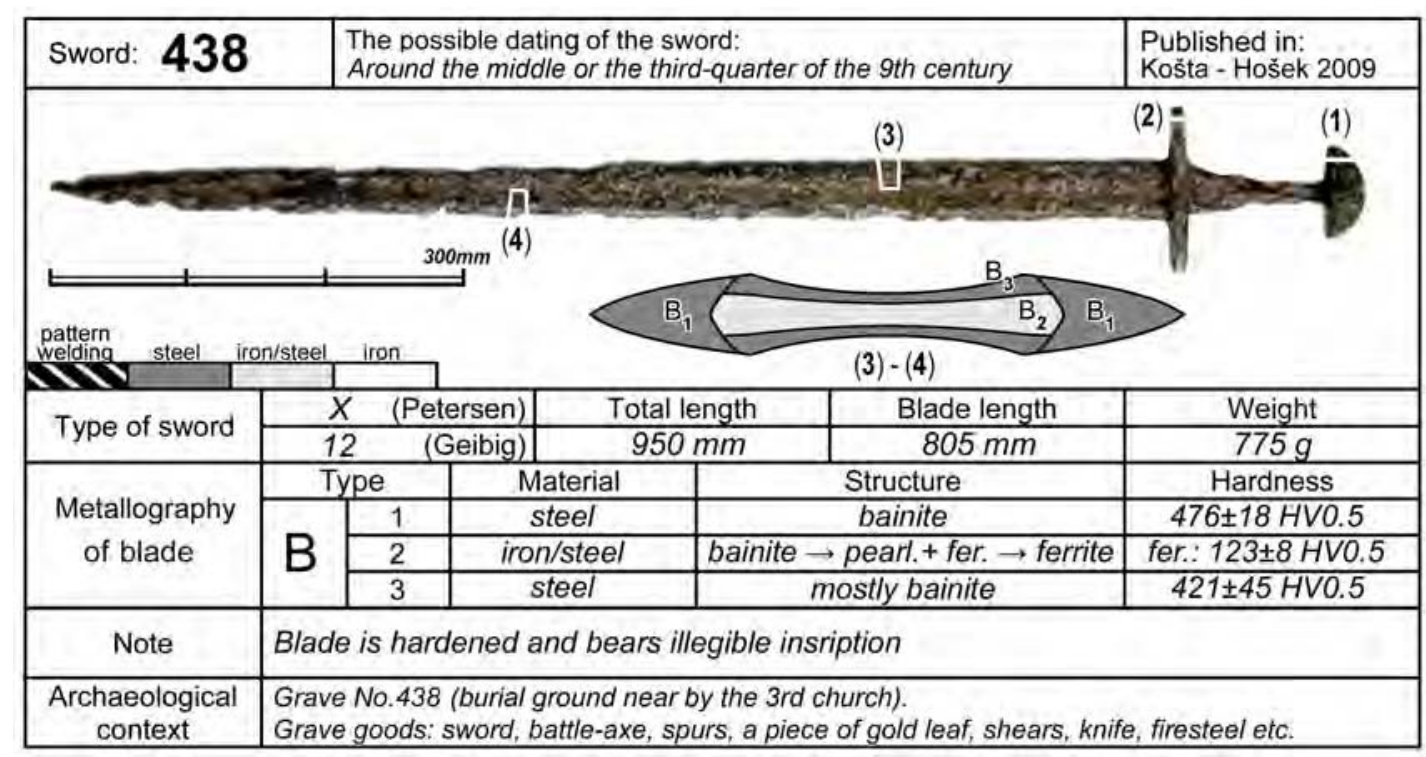

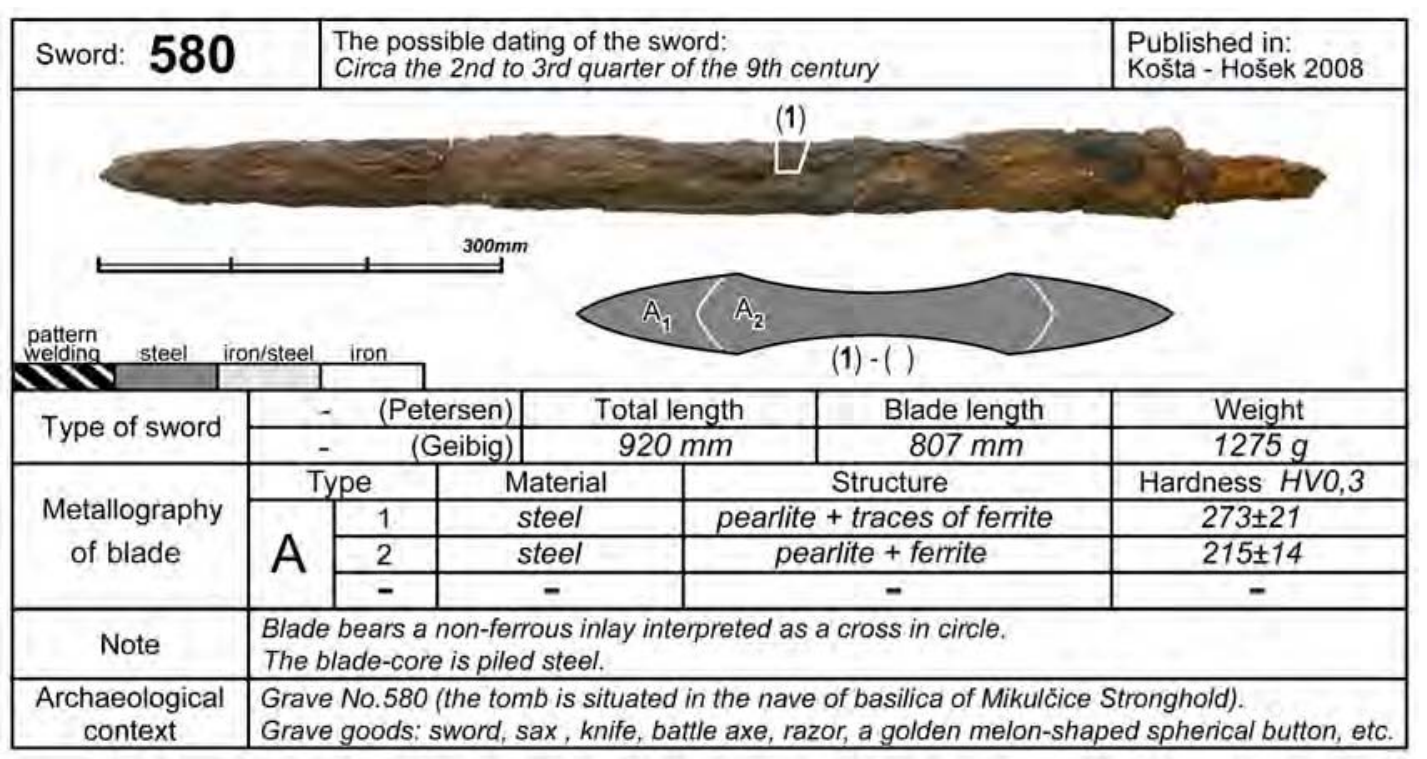




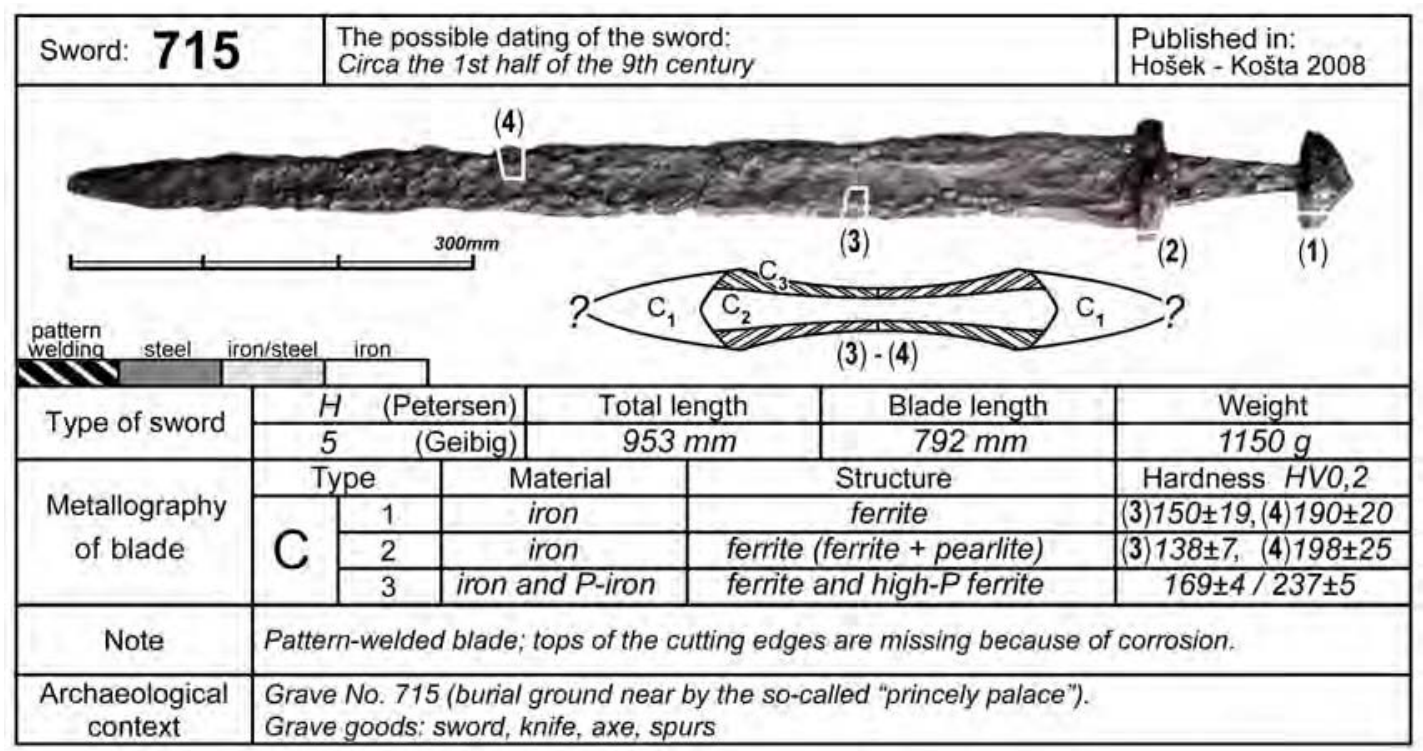

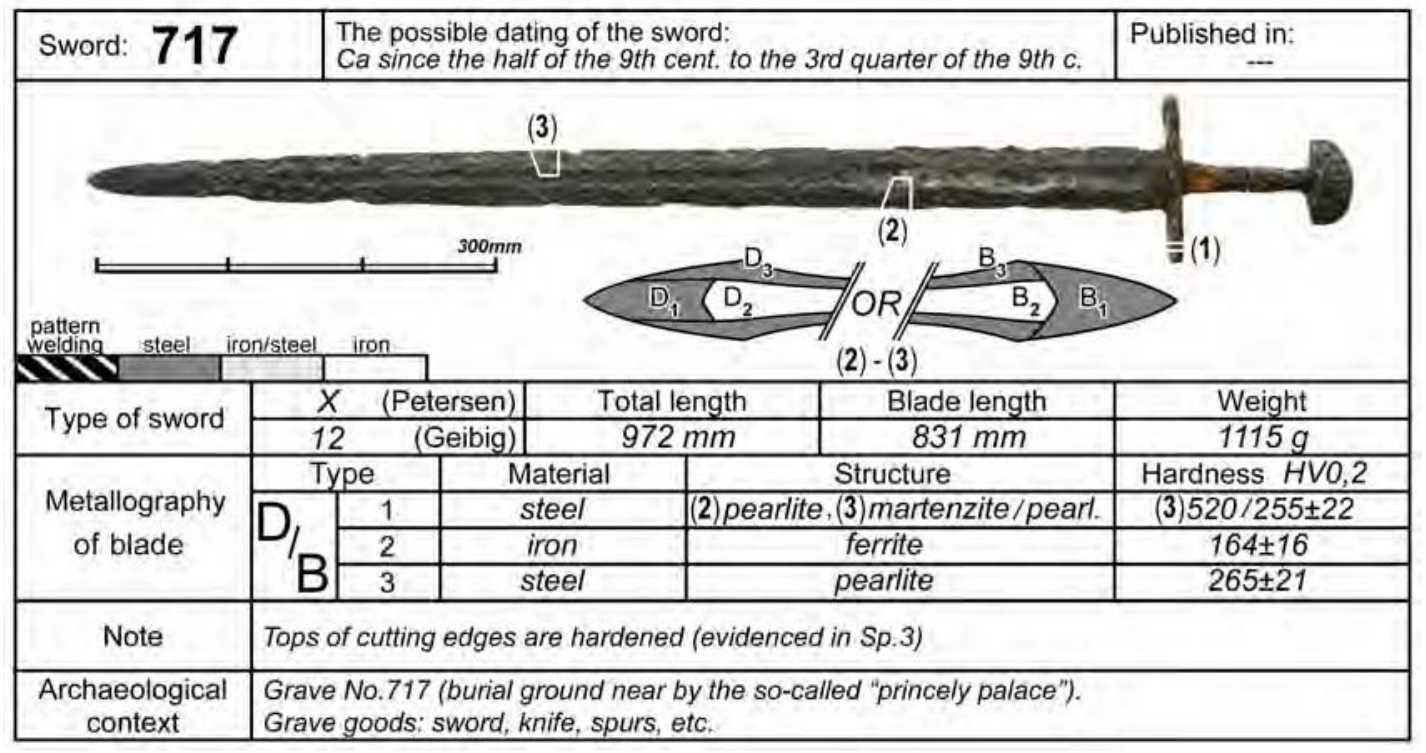




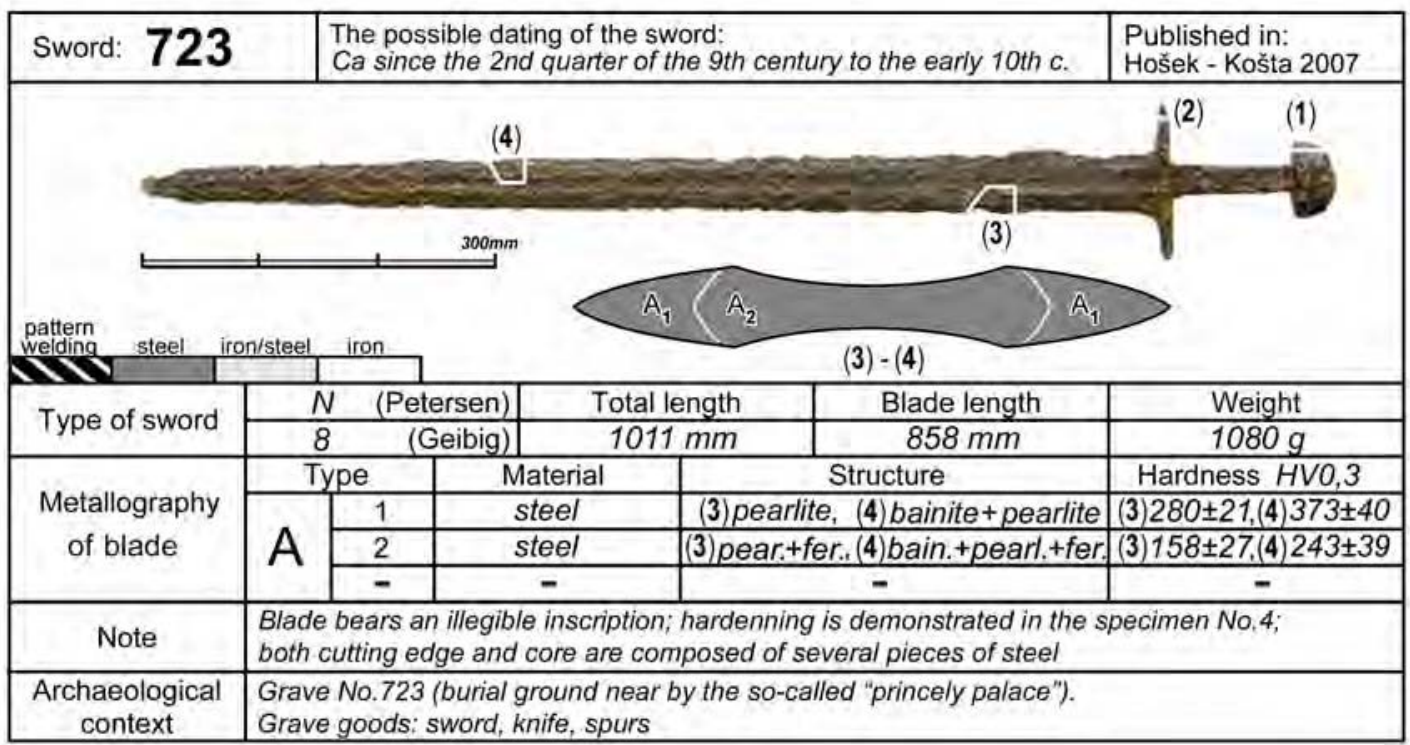

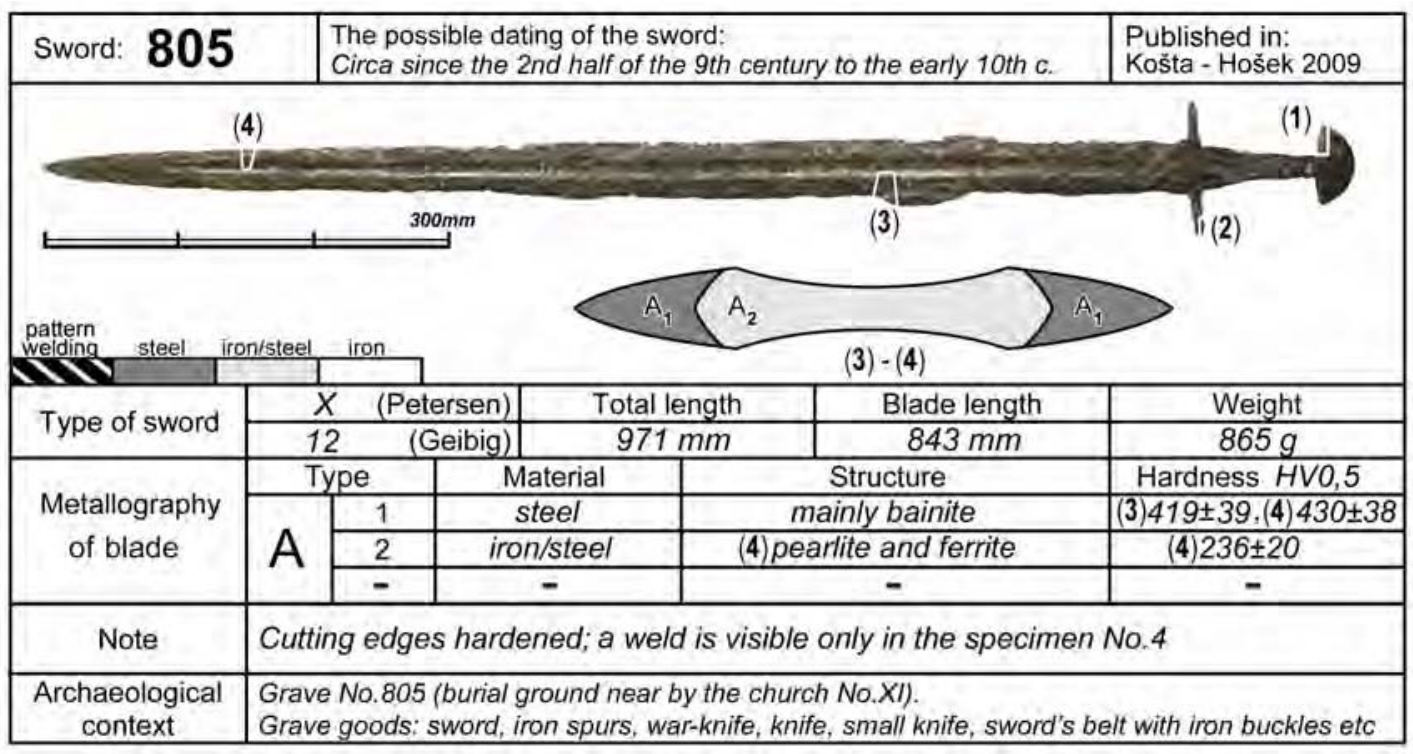




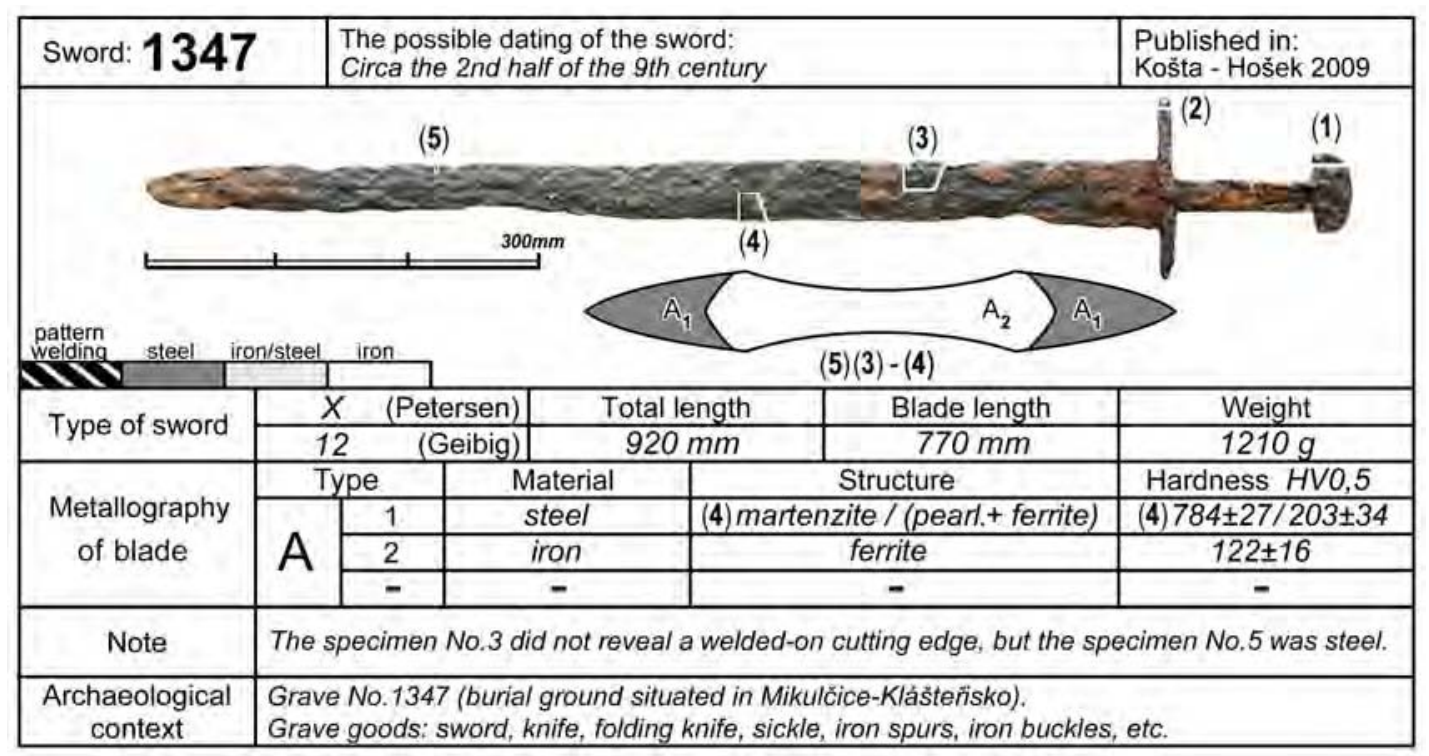

Recibido: 06/06/2010

Aceptado: 12/3/2012 